\title{
Analysis of procedures implemented by emergency medical teams in the event of cardiac arrest in the city of Lublin, Poland
}

\author{
Ewa Chemperek', Jakub Pelczar², Katarzyna Naylor', Grzegorz Nowicki', Patryk Rzońca', \\ Agnieszka Mikuła-Mazurkiewicz ${ }^{3}$, Andrzej Prystupa ${ }^{4}$ \\ ${ }^{1}$ Department of Expert Medical Assistance with Emergency Medicine Unit, Medical University of Lublin, Poland \\ 2 Public Health student, Medical University of Lublin, Poland \\ ${ }^{3}$ Chair and Department of Trauma Surgery and Emergency Medicine, Medical University of Lublin, Poland \\ ${ }^{4}$ Department of Internal Medicine, Medical University of Lublin, Poland
}

\begin{abstract}
Chemperek E, Pelczar J, Naylor K, Nowicki G, Rzońca P, Mikuła-Mazurkiewicz A, Prystupa A. Analysis of procedures implemented by emergency
\end{abstract} medical teams in the event of cardiac arrest in the city of Lublin, Poland. J Pre-Clin Clin Res. 2014; 8(1): 13-16.

\begin{abstract}
I Abstract
Aim. The aim of this study was to present an analysis of emergency teams' actions in case of cardiac arrest.

Method. The studied material consisted of emergency teams' card records with cases of cardiac arrest during the period 1 January 2010 - 31 December 2010 in the city of Lublin, Poland. The results were subjected to statistical analysis using Statistica for Windows Test 9.0, where a substantial probability was assumed at $\mathrm{p}<0.005$.

Results. The Rescue Emergency Service Station in Lublin provides four specialist teams and seven paramedic teams, ensuring the emergency services in emergency situations. They are established in three substations. During the above-specified period, 280 cases of cardiac arrest were recorded. On average, one ambulance attending incidents including cardiac arrest was dispatched 23 times a month. In addition, a considerately higher rate of such situations was noticed in Autumn and Winter. The great majority of people who experienced cardiac arrest were men $-62 \% .44 \%$ of the patients were aged $61-80$ years, $24 \%$ aged $46-60$ years, $18 \%$ over 80 years of age, $10 \%$ aged $31-45$ years and $4 \%$ aged $18-30$. The average age of the patients was 65 years. Moreover, $55 \%$ of resuscitations ended successfully. Among the factors taken under consideration were travel time, involvement of witnesses, ventilation when using a bag valve mask, use of an oropharyngeal tube, intubation, oxygen therapy, use of a ventilator, an intravenous line, central venous puncture, intraosseous infusion, and the administration of drugs. The time elapsed before arriving at the scene of the emergency amounted up to 5 minutes. Likewise, the use ofdefibrillation as well as an oropharyngeal tube greatly increased the effectivenessof CPR. Advanced age and asystole were poor prognostic factors. Additionally, witness's assistance connected with providing First Aid was recorded in $21 \%$ of cases.
\end{abstract}

\section{Key words}

cardiac arrest, emergency medicine, cardiopulmonary resuscitation

\section{INTRODUCTION}

Medication and medical procedures recommended during ALS are still being tested. Additionally, informative, randomized studies proving their ultimate impact on survival rates after a cardiac arrest are still lacking. On the basis of available literature, it has been proven that advanced treatments regarding airway management are less helpful than previously expected. This applies particularly to cardiological cases. It has been shown that in the case of intubations, the use of alternative methods of airway management, such as a laryngeal mask airway (LMA), are associated with a lower survival rate. However, a positive impact was demonstrated in connection with the use of the bag valve mask. Among the potential causes there are listed interruptions in the resuscitation required to introduce airway management procedures, and induced positive pressure in the airways, thereby reducing coronary flow $[1,2]$.

Objective. The research aimed at analysing actions undertaken by emergency medical services in Lublin

\footnotetext{
Address for correspondence: Grzegorz Nowicki, Strzembosza 3A/2, 20-153 Lublin, Poland

e-mail: grzesiek_nowicki@interia.pl

Received: 23 December 2013; accepted: 24 April 2014
}

during cardiac arrest in the period between 1 January 31 December 2010. The analysis was aimed at determining the time of arrival at the scene, type of action implemented, administration of drugs, urgency of the code calls, and the effectiveness of resuscitation. Studied material consisted of data from report charts for the above-specified period in the three ambulance service substations of Sródmieście, Czechów and Bronowice in the city of Lublin.

\section{MATERIALS AND METHOD}

Medical Emergency Response Stations in Lublin have 4 specialist teams and 7 basic teams deployed in three substations providing emergency response to sudden health hazards.

The data obtained was subjected to statistical analysis using Statistics for Windows test 9.0, where the accepted probability of significant was set at the $\mathrm{p}<0.05$ level.

\section{RESULTS}

In the analyzed period, the number of all dispatches of emergency medical teams to an event was 5,272, of which $277(5 \%)$ were cases of cardiac arrest. The average number of 
call-outs related to cardiac arrest amounted to 23 per month. During the months of February, April, October, November and December, there were slightly more cases of cardiac arrest. Comparing the 3 substations, it was found that cases of cardiac arrest and respiratory distress were experienced by teams of the 'Śródmieście' station operating in the city centre. This can be explained by a higher incidence of such situations away from home, perhaps during visits to a doctor, shops or offices. Call outs to cardiac arrest cases more often concerned men, 177 cases (62\%), than women, who accounted for 100 cases (38\%). The average age of patients in all substations in Lublin was 65 years old. The largest age group of people to which the teams were directed where CPR was undertaken, were people between the ages of 61-80 (39.7\%), followed by those aged 46-60years (31.4\%). Comparing the results from the 3 substations, no significant differences were noticed when taking into account the age of casualties.

Due to the time that elapses from receipt of the notification by the dispatcher to the departure of an ambulance team, the emergency teams are grouped into3 levels ofurgency: 1) K1 applies to life-threatening cases; the team leaves the station in less than 60 seconds in the case of such a call; 2) K2 - 31\%, 86 visits; $\mathrm{K} 3-2 \%, 5$ journeys. It is noticeable that quite a large percentage of notifications were classified in the K2 category, which does not fully correspond with the condition found at the scene - cardiac arrest. Furthermore, the causes of cardiac arrest were divided into those that were circulatory and others. As a result, the report states that $63 \%$ of situations were classified as cardiological. 151 patients (55\%) were transported to hospital after successful resuscitation, while 126 patients $45 \%$ were pronounced dead and left at the scene.

Moreover, on analysing the results, it was noted that in case of almost every casualty, chest compressions were implemented, as well as peripheral venous cannulation. An oropharyngeal tube was used in $18.8 \%$ of cases. Only very rarely the emergency teams decided to start a central line or intraosseous infusion. In addition, oxygen therapy was carried out in $63.2 \%$. Emergency teams used the respirator only in $31.4 \%$ during cardiopulmonary resuscitation, even though it significantly facilitates the work of the team, enabling them to continue life-saving procedures (Tab. 1).

Table 1. Procedures implemented during cardiopulmonary resuscitation

\begin{tabular}{lcc}
\hline \multicolumn{1}{c}{ Implemented medical procedures } & Number & Percentage $\%$ \\
\hline Suction & 125 & $45.1 \%$ \\
\hline Bag valve mask & 209 & $75.6 \%$ \\
\hline Oropharyngeal tube & 52 & $18.8 \%$ \\
\hline Tracheal intubation & 239 & $86.3 \%$ \\
\hline Medical ventilator & 87 & $31.4 \%$ \\
\hline Oxygen therapy & 175 & $63.2 \%$ \\
\hline Defibrillation & 176 & $63.5 \%$ \\
\hline Chest compressions & 267 & $96.4 \%$ \\
\hline EKG & 231 & $83.4 \%$ \\
\hline Central line & 17 & $6.1 \%$ \\
\hline Intraosseous infusion & 3 & $1.0 \%$ \\
\hline Peripheral venous catheter & 268 & $96.8 \%$ \\
\hline
\end{tabular}

In addition, the emergency teams usually applied adrenaline, atropine, and then a fairly high percentage of dopamine during resuscitation; the most commonly used fluid was physiological saline (Tab. 2). It should be noted that in many cases the report cards were filled in negligently, probably due to overwhelming emotions. Consequently, it might be worth using a different method for registering medical procedures at the scene of an accident, such as voice recorders, to improve the data collection system.

Table 2. Medicaments applied during cardiopulmonary resuscitation

\begin{tabular}{lcc}
\hline \multicolumn{1}{c}{ Implemented medicaments } & Number & Percentage \% \\
\hline Atropine & 181 & 65.3 \\
\hline Adrenaline & 244 & 88.1 \\
\hline Dopamine & 65 & 23.5 \\
\hline $\mathrm{NaCl}$ & 148 & 53.4 \\
\hline Saline & 49 & 17.7 \\
\hline
\end{tabular}

The average time of emergency teams arrival from the 'Sródmieście' station was 4.8 minutes, while the maximum travel time was 18 minutes. At the 'Czechów' station the average time amounted to 5.7 minutes, the maximum waiting time -18 minutes. The average time to reach a destination from the 'Bronowice' atation was 4.7 minutes, while the longest time was only 9 minutes. Only 'Bronowice' met the expectations reflected in the Polish Act on Emergency Medical Services.

Witnesses of these events undertook First Aid in 21.3\% of cases. Although in $14 \%$ of cases, witnesses were present at the scene of emergency, they did not commence any assistance. In other cases, information was not provided in the report cards. The report cards were completed in the most conscientious way by emergency teams from the 'Bronowice' substation.

When analysing the relationship between age and successful resuscitation, a statistically significant correlation was observed. The older the age of the patient, the chances of successful resuscitation diminished (Tab. 3). In addition, a statistically significant association between the use of defibrillation and successful resuscitation was noted defibrillation increased the chances of survival (Tab. 4).

Table 3. Relationship between age of patients and successful resuscitation; $\mathrm{p}=0.03 ; \mathrm{Chi}^{2} \mathrm{NW}-4.95$

\begin{tabular}{ccccccccc}
\hline \multirow{2}{*}{$\mathrm{N}$} & \multicolumn{3}{c}{ Unsuccessful CPR } & \multicolumn{2}{c}{ Successful CPR } & \multicolumn{3}{c}{ Total } \\
\cline { 2 - 8 } & & $\%$ & $\mathrm{~N}$ & $\%$ & $\mathrm{~N}$ & $\%$ & \\
\hline \multirow{2}{*}{ Age } & $<50$ & 7 & 15.9 & 37 & 84.1 & 44 & 100 \\
\cline { 2 - 8 } & $\geq 50$ & 74 & 31.8 & 159 & 68.2 & 233 & 100 \\
\hline
\end{tabular}

Table 4. Use of defibrillation and successful resuscitation; $p=0.0195$; Chi²NW 9.08

\begin{tabular}{lcccccccc}
\hline \multirow{2}{*}{$\mathrm{N}$} & \multicolumn{2}{c}{ Unsuccessful CPR } & \multicolumn{2}{c}{ Successful CPR } & \multicolumn{2}{c}{ Total } \\
\cline { 2 - 8 } & $\%$ & $\mathrm{~N}$ & $\%$ & $\mathrm{~N}$ & $\%$ & \\
\hline $\begin{array}{l}\text { Defibril- } \\
\text { lation }\end{array}$ & Implemented & 41 & 23.3 & 135 & 76.7 & 176 & 100 \\
\cline { 2 - 8 } & Not implemented & 40 & 40.8 & 58 & 59.2 & 98 & 100 \\
\hline
\end{tabular}

Asystole as a mechanism of cardiac arrest constituted a negative prognostic factor on the resuscitation. Ventricular fibrillation or ventricular tachycardia was observed in $50.6 \%$ of cases (Tab. 5).

It was shown that using an oropharyngeal tube significantly improved the survival rate of patients. It was connected to ventilation with a bag valve mask, which substantially increased the survival rate after cardiac arrest (Tab. 6). 
Table 5. ECG waveform and successful resuscitation; $\mathrm{p}=0.0002 ; \mathrm{Chi}^{2}$ NW -14.4

\begin{tabular}{lllllllll}
\hline & $\mathrm{N}$ & \multicolumn{3}{c}{ Unsuccessful CPR } & \multicolumn{2}{c}{ Successful CPR } & \multicolumn{2}{c}{ Total } \\
\cline { 2 - 9 } & & $\%$ & $\mathrm{~N}$ & $\%$ & $\mathrm{~N}$ & $\%$ & \\
\hline \multirow{2}{*}{$\begin{array}{l}\text { ECG } \\
\text { waveform }\end{array}$} & $\begin{array}{l}\text { Ventricular } \\
\text { fibrillation }\end{array}$ & 41 & 29.1 & 100 & 70.9 & 141 & 100 \\
\cline { 2 - 9 } & Asystole & 40 & 44.4 & 50 & 55.6 & 90 & 100 \\
\hline
\end{tabular}

Table 6. Use of oropharyngeal tube and successful resuscitation; $p=0.02$

\begin{tabular}{lcccccccc}
\hline \multirow{2}{*}{$\mathrm{N}$} & \multicolumn{2}{c}{ Unsuccessful CPR } & \multicolumn{2}{c}{ Successful CPR } & \multicolumn{2}{c}{ Total } \\
\cline { 2 - 8 } & & $\%$ & $\mathrm{~N}$ & $\%$ & $\mathrm{~N}$ & $\%$ & \\
\hline \multirow{2}{*}{$\begin{array}{l}\text { Oropha- } \\
\text { ryngeal tube }\end{array}$} & Not used & 72 & 32.1 & 152 & 68.9 & 224 & 100 \\
\cline { 2 - 8 } & Applied & 9 & 17.3 & 43 & 82.7 & 52 & 100 \\
\hline
\end{tabular}

Additionally, the study was concerned with information whether gender, the cause of cardiac arrest, intubation, ventilator connection, oxygen therapy, fluid therapy, medication, intravenous line, central and intramedullary lines, had an impact on the patients survival. However, in those cases, there was no statistically significant correlation regarding survival after cardiac arrest.

\section{DISCUSSION}

Asystole and PEA are observed in approximately 50\% of patients with cardiac arrest outside the hospital, and even $70 \%$ in the hospital. Subsequently, adrenaline is the first recommended drug, but its association with survival is still debatable. A study of 946 patients conducted in Vienna showed increased mortality, as well as increased neurological deficits after leaving the hospital after receiving adrenaline, and correlated with the total dose. In those cases, a hospital mortality of $79 \%$ and on-going dysfunction of the central nervous system were noted after leaving the hospital in $83 \%$ of cases $[3,4,5,6,7]$. In the presented study, asystolia also constituted a negative factor and was observed in almost a half of cases. Furthermore, the rhythms to be defibrillated are associated with better performance of emergency rescue procedures [6]. Most of the available studies have shown correlations between successful resuscitation with implemented early defibrillation $[4,6,8]$. A similar correlation was also demonstrated in the case of amiodarone administration [8]. The study demonstrated high efficacy when connected to the respirator and an advantage in the case of ventilation using Ambu over intubation, or the use of alternative methods of airway management. In a large study conducted in Korea, the researchers compared intubation, alternative airway management and the use of the bag valve mask in the event of cardiac arrest. There was no correlation between early survival and the admission into treatment of any of the methods. However, a positive effect was confirmed in the case of oxygen therapy and the use of a respirator $[6,9]$.

In all studies, the available literature observed a male prevalence in patients who have suffered cardiac arrest; nevertheless, interpretations of this phenomenon differ. Men are at increased risk of cardiovascular disease, pay less attention to some problems, and are less likely to seek medical attention. A study conducted in Katowice, Poland, proved this advantage in the case of $71.3 \%$ of male patients. However, life support often also had successful outcomes female patients, what was not shown in the current study $[5,6,10]$.

The importance of undertaking emergency action by witnesses is emphasized by the European Resuscitation Council as an enhancement regarding the effectiveness of resuscitation. Such a relationship was found in studies in Katowice (Rudner R, et al.), where $16.5 \%$ of the witnesses started providing First Aid [6]. The results of studies in Polish agglomeration, Łódz showed $19.1 \%$ of witnesses rendering assistance [6]. In Poznań, Poland, assistance from a witness was observed in $19.8 \%$, but it did not affect survival [8]. As in the presented study, a low number of $3.8 \%$ was noted in Łódż in the case of observers providing First Aid [7].

The effectiveness of CPR varies between $20-60 \%$. In the available literature, the results show noticeable discrepancies. The effectiveness ranges from $31.9 \%$ in Poznań, $50.6 \%$ in Elbląg, 66.7\% in Katowice, to $70.3 \%$ in Łódź $[5,7,8,10]$. Lublin, with a score of $55 \%$, constituted a desirable result.

In the obtained data, a very good time regarding arriving at the scene of an emergency was noted, but it did not affect the outcome of the emergency action. However, a positive correlation was demonstrated in a study in Katowice, especially if the arrival time of an ambulance amounted to 5 minutes [11]. The average age of patients was around 60. In the presented study, the noted age was 65 years, and data from the literature included patients aged 56 years in Elbląg and 61 years in Poznań. A negative outcome was demonstrated in the case of the percentage of survivals in elderly age, exactly as in a study conducted in Szczecin $[4,8,10]$.

The results were similar when the urgency of the request was taken into consideration. In Lublin, $\mathrm{K} 1$ calls accounted for $67 \%$ and $84 \%$ in Szczecin [4]. In their efforts to obtain the best results with resuscitation, medicaments and equipment were mentioned as important but not exclusive factors. To a large extent, this depended on the skill of the rescuers. Also, fire fighters' ability to implement successful resuscitation (Koszowska K, et al.) was tested. Two-thirds of them were not familiar with the equipment, $60 \%$ encountered difficulties when opening airways, $60 \%$ managed to correctly use the bag valve mask, $5 \%$ decided to perform mouth-to-mouth ventilation, and only one-third knew the correct order of the proceedings. In Poland, the average training time amounts to $70 \mathrm{~h}, 520 \mathrm{~h}$ in Germany, while the guidelines in the USA recommend an examination every 2 years [12].

In 2007, another study was conducted among emergency workers during the Polish Championship in Emergency Medical Services and Road Rescue. The correctness of resuscitation was estimated to be $20 \%$ effective: chest compressions at the rate of $34.4 \%$, the correct sequence was applied by $70 \%$, and the decision to use AED within 2 minutes was carried out by $90 \%$ of respondents [13]. The results indicate there is a need to pay close attention to the skills of emergency workers and their training in order to increase the chances of improving the effectiveness of resuscitation.

\section{CONCLUSIONS}

1. There is a significant deficit regarding the completion of report cards. Perhaps other methods of keeping the records of undertaken actions should be implemented, such as recorders. 
2. A negative impact has been shown regarding the administration of adrenaline, the presence of nonshockable rhythms, and the elderly age of casualties on successful resuscitation.

3. Defibrillation is the undisputed factor that increases survival.

4. Ventilation with oxygen employing a bag valve mask brings about much better results, increasing the chances of reaching a hospital.

5. More attention should be paid by the dispatcher to the appropriate coding regarding the urgency of calls.

6. A modification should be implemented in the training of rescue teams, in particularly increasing the number of hours to increase the quality of resuscitation.

\section{REFERENCES}

1. Olasveengen Theresa M, Wik L, Sunde K, Steen Petter A. Outcome when adrenaline was actually given vs. not given - post hoc analysis of randomized clinical trial, Resuscitation 2012; 83; 327-332.

2. Cone DC. Are alternative airway devices beneficial in out-of-hospital cardiac arrest editorial, Resuscitation 2012; 83; 275-276.

3. Arrich J, Sterz F, Herkner H, TestoriCh, Befringer W. Total epinephrine dose during asystole and pulseless electrical activity cardiac arrest is associated with unfavourable functional outcome and increased inhospital mortality. Resuscitation 2012; 83; 333-337.

4. Jankowski D, Czajkowski G, Janowski A, Jarosz K. Ocena wybranych czynników wpływających na skuteczność resuscytacji w nagłym zatrzymaniu krążenia poza szpitalem w materiale Oddziału Intensywnej Terapii i Anestezjologii Szpitala Wojewódzkiego im. M. SkłodowskiejCurie w Szczecinie. Med. Intens. Rat. 2004; 7(4); 187-194 (in Polish).
5. Rudner R, Jałowiecki P, Wartak M, Marciniak R, Byrczek T. Ocena wybranych czynników wpływających na wyniki postępowania resuscytacyjnego w pozaszpitalnych zatrzymaniach krążenia. Anest. Int. Ter 2005; 37; 174-180 (in Polish).

6. Rasmus A, Kołodziajczyk-Wojtczak D, Balcerzyk-Bardzo E. Wpływ postępowania resuscytacyjnego na przeżycie chorych po pozaszpitalnych zatrzymaniach krążenia na terenie łódzkiej aglomeracji miejskiej oraz analiza długości i jakości życia. Med. Intens. Rat. 2005; 8 (4) 183-193 (in Polish).

7. Januszewski J. Analiza podjętych resuscytacji przez wybrany zespół reanimacyjny w Łodzi. Med. Intens. Rat. 2007; 10(1) 19-25 (in Polish).

8. Roman M, Gaca M. Analiza podjętych czynności w zewnątrzszpitalnym nagłym zatrzymaniu krążenia przez wybrane zespoły ratownictwa medycznego w Poznaniu. Med.Intens. Rat. 2008;11(2) 93-100 (in Polish).

9. Sang DS, Ki OA, Kyoung JS, Chang BP, Eui JL. Out-of-hospital airway management and cardiac arrest outcomes: a propensity score matched analysis. Resuscitation 2012; 83; 313-319.

10. Czerniewski A, Basiński A, Jaśkiewicz M. Ocena skuteczności resuscytacji krążeniowo-oddechowej na podstawie działalności Działu Ratownictwa Medycznego w Elblągu. Med. Intens. Rat. 2004;7(4): 195-199 (in Polish).

11. Rudner R, Jałowiecki P, DziurdziukP, Karpel E, Kawecki P, DudekDyczkowska D, Willand M, Wyniki postępowania reanimacyjnego w pozaszpitalnych zatrzymaniach krążenia o etiologii kardiologicznej, Anestezjologia Intensywna Terapia 2004; 36; 267-275 (in Polish).

12. Koszowska K, Guła P, Larysz D, Nitecki J, Nabzdyk A, Maślanka M, Ocena jakości udrażniania dróg oddechowych i ocena efektywności wentylacji wykonywanych przez wykwalifikowanych ratowników przedmedycznych, Medycyna Intensywna i Ratunkowa, 2007; 10 (4); 215-221 (in Polish).

13. Guła P, Koszowska M, Larysz D, Koszowski M, Nitecki J, Nabzdyk A, Maślanka M, Ocena skuteczności działań resuscytacyjnych wykonywanych przez polskich ratowników Anestezjologia Intensywna terapia 2008; 40; 237-240 (in Polish). 